УДК: [94(477.83/86):070.447(438:477)]"1930"

DOI: 10.33402/up.2020-13-243-256

\author{
Magdalena GIBIEC \\ Researcher, PhD Student \\ University of Wroclaw \\ Institute of History \\ ORCID: 0000-0001-9217-7943 \\ e-mail: gibiec_magda@wp.pl
}

\title{
THE IMAGE OF PACIFICATION OF EASTERN HALYCHYNA IN 1930 IN LIGHT OF POLISH AND UKRAINIAN PRESS
}

The pacification conducted by the Polish authorities in Eastern Halychyna in 1930 was the consequence of conflict escalation and pressure put by both the Polish and Ukrainian sides since the end of World War I. As a result of the Treaty of Riga of 1921 and finally, the provisions of the Conference of Ambassadors in 1923, a large percentage of Ukrainians found themselves on the Polish side of the border against their will. Attempts to regain their independence and the fight undertaken in 1918 ended in failure, which only intensified the conflict $^{1}$. In addition, the inefficient national policy of Poland, as well as the unwillingness to cooperate with the Ukrainians, made it impossible to find a satisfactory solution to the issue. For both the Polish and the Ukrainians, Eastern Halychyna was a priority. There was no such compromise that could meet the expectations of both sides. Social attitudes among the Ukrainians favored the radicalization of their views and led to the rise of nationalism. In 1920, the Ukrainian Military Organization (UMO) was established, which has set itself the goal to continue the fight for independence against Poland using even more extreme methods ${ }^{2}$. UMO's activists were fighting not only against the Poles but also the Ukrainians who were ready to establish cooperation with the Polish Government. The next couple of years brought more sources of disagreement, such as the issue of Ukrainian education and economic reform, which only deepened the conflict. Under such conditions, the crisis erupted. In June of 1930, the public was informed about the alleged negotiations between the Government and the Ukrainian National Democratic Alliance (UNDA). This led to the mobilization of Ukrainian nationalists coming out against any agreement. It was connected to the rise of the Organization of Ukrainian Nationalists (OUN), and UMO became an armed part of it $^{3}$. Taking drastic measures, they wanted to prevent the agreement and raise the national issue. It resulted in the

1 Tomaszewski J. Rzeczpospolita wielu narodów. Warszawa: Czytelnik, 1985. S. 16.

2 Мірчу́к П. Нарис історії Організації Українських Націоналісті. Київ: Українська видавнича спілка, 2007. С. 20.

3 Motyka G. Ukraińska Partyzantka 1942-1960. Działalność Organizacji Ukraińskich Nacjonalistów i Ukraińskiej Powstańczej Armii. Warszawa: Rytm, 2006. S. 46-47. 
so-called partial pushback of UMO. First, the sabotage and later on the pacification affected, directly and indirectly, a huge part of the population living in the area of Eastern Halychyna.

In the era, when there were practically no other mass media, the press was the most important public mouthpiece. It not only served an informative function, but its primary goal was opinion-forming. The press significantly influenced the attitudes and moods of the nation and could even change the course of action. By manipulating the facts, using the right language, fighting with arguments, the press was able to create the desired picture of the events. By looking at the events through the prism of the press, we can look at them from the inside, and thanks to the regularity of press publication (daily in this case), we can follow their development. The aim of this paper is to present the selected issues related to the events, named by the historiography as «the pacification of Eastern Halychyna», in the light of archival materials as well as Polish and Ukrainian public opinion expressed in the press: the «Słowo Polskie» and the «Dilo».

Keywords: pacification, Polish and Ukrainian public, Eastern Halychyna, Ukrainian National Democratic Alliance, Ukrainian Military Organization, Organization of Ukrainian Nationalists, Polish Government.

The so-called second pushback of UMO-OUN, which highest intensity was observed between July and September 1930, was a very risky step from the side of Ukrainian nationalists; still, it turned out to be effective. The acts of sabotage were mainly performed by the youth from OUN as well as UMO militia groups, but it was not only them. Also, many young people, lured by more visible effects of nationalist actions than the positivistic work of the legal organization, engaged themselves in participation in subversive actions. The acts of sabotage were mainly arson attacks on property, usually farm buildings and haystacks, not only of Polish settlers but also the Ukrainians loyal to the Polish state. Other targets of the attacks included administrative buildings, mail cars, bridges, roads, railways as well as telephone and telegraph wires. The saboteurs also carried out intimidating actions against the Jews in order to protect Ukrainian cooperatives from the competition. Official sources reported 191 such acts of sabotage (172 on private property and 19 on state property) $)^{4}$. Ryszard Torzecki mentioned even more than such 2000 incidents $^{5}$. One of the most notorious cases was the attack on the postal ambulance near Bibrka on July 30th, 1930, during which 26 thousand zlotys were robbed, and a patrolman Joseph Molewski was killed. One of the perpetrators of the attack also died in this event. Bohdan Kordiuk, an OUN member, was accused of organizing the robbery and sentenced to 1.5 years in prison. According to the Polish press, Ukrainian nationalists, who were also members of the youth organization «Plast» and pupils of «Ruthenian»s schools, were also involved in the attack. Therefore, polish public opinion raised a voice to perform detailed inspections in Ukrainian organizations and schools ${ }^{6}$.

4 Szumiło M. Ukraińska Reprezentacja Parlamentarna w Sejmie i Senacie RP (1928-1939). Warszawa: Neriton, 2007. S. 139.

5 Torzecki R. Kwestia ukraińska w Polsce w latach 1923-1929. Kraków: Wyd-wo Literackie, 1989. $470 \mathrm{~s}$.

6 Napad rabunkowy bojówki UOW na ambulans pocztowy pod Bóbrką. Słowo Polskie (Lwów). 1930. 1 sierpnia. 
The «Dilo» protested against such a practice in its articles and emphasized that social organizations could not have anything to do with Ukrainian nationalists working secretly?

The acts of sabotage sparked nationalistic sentiments among Polish people. Due to intensified attacks, which touched a large part of the population of Eastern Halychyna, since the beginning of September, massive protests and street demonstrations were organized, and they lasted for the entire time of pacification. During the demonstrations, which were also attended by representatives of Polish political parties, mainly the issue of the need for a strong government response to these events was raised, in particular, to inspect Ukrainian schools and organizations from which the saboteurs had been recruited $^{8}$. They also pressed to dismiss teachers of Ukrainian origin, or at least to move them to the «native Polish lands» ${ }^{9}$. They threatened that if their postulates were not introduced, people would have to seek justice on their own. The answer to the sabotage was a pacification campaign carried out in accordance with the decree of Józef Piłsudski by the joint force of the army, the police, and local population in three provinces: Lviv, Ternopil, and Stanislaviv (Ivano-Frankivsk now) ${ }^{10}$. It was the biggest confrontation between the two nations since the end of the Polish-Ukrainian war, as well as one of the most serious challenges for internal security since regaining independence.

The term pacification can be a bit ambiguous, especially with regards to the classification of individual actions as acts of pacification. Therefore, it is hard to tell the exact time of the action. In modern studies, we usually see the date from September 16th to November 30th, $1930^{11}$. The term refers to the action conducted under the direct command of Marshal Józef Piłsudski and executed by the Minister of Internal Affairs - Felicjan Sławoj Składkowski. The campaign was supervised by Czesław Grabowski, commandant of the voivodship State Police in Lviv ${ }^{12}$. A slightly different picture was presented by the newspapers. In the «Słowo Polskie», the first information about the beginning of the pacification was given on September $23 \mathrm{rd}^{13}$. It referred only to operations with the most intense activity of pacification divisions, namely sending more than 1,000 policemen and officers to the areas affected by sabotage actions which took place the day before, on September $22 \mathrm{nd}^{14}$. However, it mentioned neither the arrests and searches that had been carried out since August by the local police nor sending the 14th Uhlan Regiment to the province

7 Напад на почтовий амбулянс. Діло (Львів). 1930. 1 серпня.

8 Przeciw zakusom pruskim i bandyckim prowokacjom ukraińskim. Słowo Polskie. 1930. 2 września.

9 Центральний державний історичний архів України, м. Львів (далі - ЦДІАЛ України). Ф. 344. Спр. 6. Т. 1. Арк. 7.

${ }^{10}$ Szumiło M. Ukraińska Reprezentacja Parlamentarna w Sejmie i Senacie RP (1928-1939). Warszawa: Neriton, 2007. C. 139.

${ }^{11}$ Motyka G. Ukraińska Partyzantka 1942-1960. Działalność Organizacji Ukraińskich Nacjonalistów i Ukraińskiej Powstańczej Armii. Warszawa: Rytm, 2006. C. 57.

${ }^{12}$ Wysocki R. Organizacja Ukraińskich Nacjonalistów w Polsce w latach 1929-1939. Lublin: Wyd-wo Uniwersytetu Marii Curie-Skłodowskiej, 2003. C. 130.

${ }^{13}$ Oczyszczenie trzech województw ze zbrodniczych elementów. Słowo Polskie. 1930. 23 września.

14 Ibid. 
of Lviv in mid-September. Military troops were reported to stay in Eastern Halychyna until mid-October, which was also confirmed by the «Słowo Polskie» ${ }^{15}$. Nevertheless, the «Diło» reported further criminal expeditions after the alleged withdrawal of the military forces: «army and police still «pacify» Halychyna, returning the second and the third time to already «pacified» towns and widen their activity more and more to locations where non «sabotages» had place» ${ }^{16}$. For the Ukrainian press, pacification comprised all the actions taken by the authorities that were striking the Ukrainian population in this area from the beginning of September until the end of the year, at least.

Although the proper pacification action with the participation of the army and police started in the second half of September, preventive actions with the help of the local police started at the beginning of the month. The pre-pacification action included searches and arrests of suspects on a scale that was not smaller than later on during the most intensive actions. In addition to the already given example of the arrests from the end of August, on September 4th, as reported by the «Dilo», 100 police officers performed searches near the village of Zhydiatychi. The searches took place in the morning and were aimed mainly at the so-called «conscious farmers» who were sending their children to school in Lviv ${ }^{17}$. It was confirmed by the memorandum of UNDA addressed to the Polish Government in January 1931: «The uhlans arrived in the village Hermanowa in the administrative division of Lviv. Having a list of conscious farmers in their hands, they marked their houses with a red pencil [...] Houses of the richest farmers of Hermanowa were marked with the red pencil, and only for their descent work in the village, they had to expect the conquests of the uhlans. Having seen what was going on, they fled from the village and hid themselves in the forests $\rangle^{18}$. Revisions of private properties continued throughout the period of the pacification campaign, and the results presented by the Government were to justify their legitimacy and necessity of further searching of houses. Revisions had to be very tedious and detailed; looking in the cabinets with underwear, searching the corn and hay cones, looking under the paintings by smashing glass and frames, opening containers with food, and pulling out roofs. According to the Ukrainian press, nothing was found ${ }^{19}$. The «Słowo Polskie» also mentioned the revisions but in a very laconic way, claiming that the results were confidential ${ }^{20}$.

Another element of the pre-pacification campaign was the implementation of borough/municipality watch and curfew ${ }^{21}$. In some villages, the Ukrainian population refused to fulfill this obligation. In such a case, at the request of the administrative authorities,

\footnotetext{
${ }^{15}$ Akcja pacyfikacyjna ukończona. Słowo Polskie. 1930. 12 października.

163 голосів української преси про події в краю. Діло. 1930. 21 жовтня.

${ }^{17}$ Масові ревізії по селах львівського повіту. Діло. 1930. 18 вересня.

${ }^{18}$ Pl.: «przybyli ułani do wsi Hermanowa lwowskiego pow. mając spis uświadomionych włościan w ręku znaczyli ich domy czerwonym ołówkiem. [...] naznaczono czerwonym ołówkiem domy najpoważniejszych włościan Hermanowa i tylko za ich kulturalna pracę we wsi oczekiwały ich podboje ułanów. Wszyscy oni widząc na co się zanosi uciekli ze wsi i pochowali się w lasach»; ЦДІАЛ України. Ф. 344. Спр. 6. Т. 1. Арк. 7.

${ }^{19}$ ЦДІАЛ України. Ф. 344. Спр. 6. Т. 1. Арк. 7.

${ }^{20}$ Rewizje w Żydatyczach i w okolicy. Słowo Polskie. 1930. 7 września.

${ }^{21}$ Документ часу. Діло. 1930. 10 вересня.
} 
soldiers were quartered in the troubled region. It was the case for the village of Kurowce, whose inhabitants refused to execute the command twice. As a result, the squadron of the 9th Uhlan Regiment was billeted in the village at 3 o'clock in the morning ${ }^{22}$. The presence of regiment was very inconvenient for the villagers as it was connected to additional commitments as well as abuses. Still, according to the Polish press, it was often the only possible and effective way to restore order. After the promise of the Municipal Council of complete subordination to the directives of the authorities, the squadron was withdrawn and directed to other places of sabotage actions ${ }^{23}$.

The action of pacification, in the strict meaning of the word, was widely reported and commented on by both the Polish and Ukrainian press. The «Słowo Polskie» presented daily results of the pacification divisions, which was supposed to show the importance of actions taken by the authorities. Numerous arrests and the results of the revisions were to confirm the thesis about the cooperation of Ukrainian organizations with UMOOUN and the involvement of young people in the acts of sabotage. Another prominent argument was the closing of Ukrainian middle schools and youth organizations where, according to press reports, a lot of incriminating material was found. The «Dilo» also reported in its articles about daily pacification actions; however, its aim was to discredit them and emphasize the groundlessness and meaninglessness of searches and arrests that were meant to intimidate the Ukrainian population.

The most controversy during the pacification campaign was aroused by the actions of the Ukrainian cultural, educational, and economic organizations, as well as secondary schools where lessons were taught in the Ukrainian language. According to Polish publicity, the saboteurs were recruited by UMO-OUN from these organizations. In fact, it was believed that without the support of the local population, Ukrainian nationalist organizations would not be able to act on such a large scale. Voices for the elimination of the «cradle» of nationalists appeared in the Polish press in early September. The «Słowo Polskie», in the article from September 9th, «Ruthenian secondary schools - hatcheries of rebels», stated openly that Ukrainian schools' students took part in acts of sabotage. As proof, they mentioned numerous arrests, during which it turned out that the vast majority of the detainees were students. Another example might be the slogan: «Damn the Lachs, who stole Ukraine as far as Krakow» ${ }^{24}$, which was put up at the railway station in Pidberiztsi (province Lviv), and young people were standing and throwing stones at passing trains ${ }^{25}$. At the station in Vynnyky (near Lviv), perpetrators were caught red-handed while they were blurring Polish national symbols and replacing them with a trident sign. Among the detained, there were also students of Lviv schools ${ }^{26}$. However, not only the students were punished but also the teachers working in these schools. Searches carried out in the Ukrainian institutions before the proper pacification action provided evidence

\footnotetext{
${ }^{22}$ Za sabotowanie zarządzeń władz zakwaterowano we wsi Kurowce szwadron ułanów. Słowo Polskie. 1930. 20 września.

${ }^{23}$ Kwaterunek ułanów po wsiach daje dobre wyniki. Słowo Polskie. 1930. 24 września.

${ }^{24}$ Pl.: «Niech szlag trafi Lachów, bo ukradli Ukrainę po Kraków».

${ }^{25}$ Ruskie szkoły średnie - wylęgarniami wywrotowców. Słowo Polskie. 1930. 9 września. ${ }^{26}$ Ibid.
} 
for arresting three high school professors from the «Ukrainian Society of Education» in Rohatyn, which was described as a «citadel of subversive work» ${ }^{27}$. After the next searches, the «Słowo Polskie» reported about finding a hand grenade and three rockets in the attic, and the newspaper emphasized that they were to be used «to set the piles on fire» ${ }^{28}$. Another school suspected of «raising arsonists» was the state high school with the «Ruthenian» language of instruction in Ternopil, which was attended by perpetrators of arson actions in several nearby villages ${ }^{29}$. Both schools were closed on September 26th in accordance with the Regulation of the Minister of Religious Affairs and Public Enlightenment-Sławomir Czerwinski. He commented on this decision in the following way: «Being personally far from a tendency to repress the aspirations and rights to cultivate the Ukrainian culture, I am at the same time determined to root out all the exploits which, under cover of cultural work, promote violence against the state and part of its population $»^{30}$. At the beginning of November, a private school in Drohobych was also closed, and its director, in the light of evidence incriminating him and his school, was put in prison $^{31}$. However, it had not stopped activists from other middle schools. Apart from acts of sabotage carried out by students, additional incidents such as throwing the president's portrait out of the window or destroying the national emblem sign were also noted. All these incidents took place in a gymnasium with the Ukrainian language of instruction in Lviv, and as a result, the school was also closed ${ }^{32}$.

One of the unresolved issues was the possible participation of Polish youth in retaliatory arsons of Ukrainian institutions and several Jewish shops. It was believed that the event had a clearly national-democratic character ${ }^{33}$. The «Słowo Polskie» was fighting these arguments treating them as the Ukrainian provocation. A good example of this fight was how the two newspapers described the explosion that took place at night on September 20th in one of the Ukrainian schools in Lviv. The «Dilo» was convinced about planting a bomb and the «Słowo Polskie» about an explosion of the materials that had been already stored in the school building ${ }^{34}$. On October 2nd, there was another explosion, this time in the Ukrainian Tsentrosoiuz. Again, the two newspapers presented a completely different assessment of the causes and the course of the explosion. The «Dilo», in an extensive article, emphasized the widespread propaganda of the Polish

${ }^{27}$ Nici sabotaży bobreckich prowadzą do «ukraińskiego» gimn. w Rohatynie. Ibid. 18 września.

${ }^{28}$ Ruskie gimnazjum arsenałem sabotażystów. Dalsze wyniki ekspedycji 1000 posterunkowych. Ibid. 25 września.

${ }^{29}$ Ruskie gimnazjum w Tarnopolu wychowuje podpalaczy. Ibid. 22 września.

${ }^{30} \mathrm{P} 1 .:$ «Będąc osobiście jak najbardziej daleki od tendencji thumienia dążeń i praw, mających na celu pielęgnowanie kultury ukraińskiej, równocześnie jestem zdecydowany tępić z korzeniami wszystkie te wyczyny, które pod płaszczykiem pracy kulturalnej hodują elementy walki z państwem i częścią jego ludności»; Zamknięcie dwóch gimnazjów ruskich. Ibid. 29 września.

${ }^{31}$ Prywatne ukraińskie gimnazjum w Drohobyczu - zamknięte. Ibid. 5 września.

${ }^{32}$ Znieważenie portretu prezydenta w lw. gimn. ruskiem. Ibid. 13 października; Zniszczenie orła państwowego w gimnazjum ruskiem. Ibid. 27 października.

${ }^{33}$ Mazur G. Życie polityczne polskiego Lwowa 1918-1939. Kraków: Księgarnia Akademicka, 2007. C. 129-130.

${ }^{34}$ Українська школа ім. князя Льва у Львові вилетіла у воздух. Діло. 1930. 23 вересня. 
press, urging in its articles to retaliate. That was the cause of antagonizing relations between Poles and Ukrainians during such a difficult period of 1930. According to the «Dilo», when the Ukrainian institutions were subject to the act of sabotage, in such circumstances, it was easy to blame the Ukrainians themselves. The newspaper also stressed: «In short, Polish chauvinistic press [...] apparently forgot all the exhortations to «self-defense» and revenge, which it put on its pages and it does not want to believe that anyone from the Polish side wants to put into practice ${ }^{35}$. Without any doubt, according to the Ukrainian press, other actions, such as setting fire to the stands of the football club «Czarni» or an assassination attempt on Panorama Racławicka, should also be attributed to «provocateurs and speculators» ${ }^{36}$. The «Dilo» opposed defenseless Ukrainian society to the Polish Government that was in the position of strength but still attributed numerous provocations to the Ukrainian «auto-sabotage» ${ }^{37}$.

The action of pacification cannot be discussed without the context of other events taking place at this time in Poland. First of all, it is about the preparations for new elections to the Sejm and the Senat for the third term, that were planned respectively for November 16th and 23rd, 1930. The arrests of former Members of Parliament (MPs), both Polish and Ukrainian, were inherent in the pacification and the elections. The arrests began at night from September 9th to 10th and were perceived as a part of the political games against the opposition. The first information about the arrests appeared in the press only on September 12th. The «Słowo Polskie» reported that the reason for the arrests of former Ukrainian Members of Parliament was their activity against the state. Officially, they were accused of high treason, pointing at a possible agreement with the Soviet Union, as well as their connection to the sabotage ${ }^{38}$. Nonetheless, it was rather obvious that the main reason for the arrests was preventing the MPs from standing to Parliament in November. On the other hand, the arrests were not completely unjustified. For example, Dmytro Paliiv had been organizing the activity of UMO-OUN before he joined the UNDA. He had been editing the newspaper «Novyi Chas», which was recognized by the «Słowo Polskie» as «highly anti-polish $»^{39}$. Besides him, it was out of the question that two other MPs were previously linked to UMO-OUN. However, their popularity was the reason why the arrests happened at that time. There was a fear of entering the Parliament by people from the right side of UNDA, which stood in opposition to a conciliatory policy with the Polish Government. Arrests continued and focused on the activists associated with different political fractions, who enjoyed a lot of electoral support.

The Ukrainian press perceived the arrests as one of the pacification methods, which was part of a general fight against Ukrainians, inter alia by preventing them from being a part of legislative power. The «Słowo Polskie», as opposed to the «Dilo», did not even mention any political reasons for the arrest of Ukrainian MPs. However, it admitted that

${ }^{35} \mathrm{Ukr}$.: «Словом польська шовіністична преса [...] очевидно забула всі ті покликі та заклики до» самооборони і реванжів, які містила на своїх сторінках і не хоче вірити, щоби їх хто-небудь $з$ польскої сторони проводив тепер у життя»; Реванжі. Там само. 5 жовтня.

${ }^{36}$ Пацифікація і реванжі. Там само. 24 вересня.

${ }^{37}$ Реванжі. Там само. 5 жовтня.

${ }^{38}$ Przyczyny środowych aresztowań. Słowo Polskie. 1930. 13 września.

${ }^{39} \mathrm{Pl}$.: «polakożercze»; Echa wczorajszych aresztowań. Ibid. 1 października. 
it was a big risk taken by the Government. If the accusations had proved to be true, it could have been complete discrediting of the opposition parties. If they had not, this event would have brought them success in the fight against the Sanation ${ }^{40}$. So, it is believed that the time of their arrests was not accidental but rather strongly associated with the upcoming elections. After nearly two months under arrest, five of the former MPs and political activists were transported from the fortress near Brest to Lviv, where they were put on trial ${ }^{41}$. As a result of the trials, which took place after the so-called Brest elections, the penalties proved to be surprisingly mild in comparison to the accusations.

Probably, the main source of disagreement over the events in Eastern Halychyna was the argument constantly put forward by the Ukrainians that the entire Ukrainian society was burdened with collective responsibility for the acts of sabotage, and the pacification should not have been aimed at innocent people. The Ukrainians perceived it not only as revenge for the acts of sabotage but also an attempt to crack down on the Ukrainians in general. This issue was raised in the first days of September and was also addressed in international for a long after the pacification as the main argument against the pacification. Initially, the «Dilo» rushed to defense the Ukrainians against placing full responsibility for the sabotage on them. It insisted that only $50 \%$ of the acts of sabotage could be chalked up on the Ukrainians. The remaining 50\% was recognized as activities of insurance speculators (who would set their own piles of grain on fire in order to obtain compensation) as well as provocateurs and so-called «defenders of Polishness on the borderlands $»^{42}$. The «Dilo» emphasized that it was not only Polish properties but also Ukrainian personal and cooperative estates that were attacked by saboteurs. Therefore, it was impossible that the Ukrainian population participated in these attacks. Thereby, the newspaper renounced any UMO-OUN actions ${ }^{43}$.

From the very beginning, Ukrainians were actively protesting against the antiUkrainian propaganda campaign propagated in the Polish press. They objected to the name «Ukrainian sabotages» ${ }^{44}$, considering it unjust at the point when the nature of the arson and the culprits hand not been established ${ }^{45}$. The problem of the so-called «smear campaign» against everything that was Ukrainian was strongly emphasized by the «Dilo» as one of the examples of unfair treatment of the Ukrainian population. On October 1st, a message issued by three main Ukrainian political parties (the Ukrainian National Democratic Union, the Ukrainian Socialist-Radical Party, and the Ukrainian Social Democratic Party) appeared in the «Dilo». It presented their views on the latest events in Eastern Halychyna. First and foremost, it was considered that the Ukrainian society could not be responsible for the actions of organizations that were not controlled by them. «Innocent and defenseless [...] society» ${ }^{46}$ fell victim to the campaign of the Polish press and

\footnotetext{
${ }^{40}$ Przyczyny środowych aresztowań. Ibid. 13 września.

${ }^{41}$ Z Brześcia przewieziono do Lwowa 5 b. posłów «ukraińskich». Ibid. 15 listopada.

${ }^{42} \mathrm{Pl}$.: «obrońców polskości na kresach».

${ }^{43}$ Głos niepokoju w prasie ruskiej. Słowo Polskie. 1930. 22 września.

${ }^{44} \mathrm{Ukr}$.: «українських саботажів».

${ }^{45}$ Президія УНДО до мін. Складковського. Діло. 1930. 2 вересня.

${ }^{46} \mathrm{Ukr}$. «Невинне і везвронне [...] населення».
} 
activities striking at them. Protests were also made against «illegal actions by so-called pacification troops $\gg{ }^{47}$, which threatened the lives and health of the inhabitants, as well as the cultural achievements of the Ukrainians ${ }^{48}$. In fact, this last fragment was censored due to undermining the legitimacy of state action. The message ended with a statement in which it was recommended not to give up in these difficult times and continue working ${ }^{49}$.

Due to another explosion in one of the Ukrainian institutions, which was blamed on the «Ruthenian» society, Ukrainian representatives of cultural and economic organizations met with the district governor and protested against the accusations in the Polish press. They also asked for police protection of the Ukrainian institutions and insisted on performing searches in order to prove that no explosives were stored in them. As reported by the «Dilo», the district governor decided that he could not be responsible for what the Polish newspapers wrote and that there were neither sufficient financial resources nor a substantial need for police protection. He also refused to perform searches explaining that these organizations could prepare themselves for the revision and only after it had finished put the explosive materials back in place ${ }^{50}$. However, what was written in the «Dilo» was undermined both by the «Słowo Polskie» and by the district governor. He sent a correction that slightly changed the meaning of his words paraphrased by the «Dilo», in which he stated that the lack of influence on the Polish press was not due to the inability to do so, but from the lack of reason to do it, as the Polish press wrote about the actual results of the ongoing investigations and revisions ${ }^{51}$.

With the intensification of the pacification campaign, the views of Ukrainian public opinion were also radicalized. People believed that the participation of Ukrainians in sabotages had to be minimal (no more than 50\%), and most of them were the already mentioned «speculators and provocateurs $\rangle^{52}$. They would have two goals: to turn Polish public opinion against the Ukrainians and bring repressions upon them, as well as a political goal which would be (as it was formulated by the press) «update of anti-Ukrainian slogans $\rangle^{53}$ by political parties ${ }^{54}$.

According to the «Słowo Polskie», the pacification campaign was carried out only among the «notoriously troubled circles», which constituted only a few percent of the total. In addition, it was emphasized that the pacification actions were conducted only in the districts affected by the acts of sabotage and not in the whole Eastern Halychyna. As it was written repeatedly in subsequent articles, the population of «Ruthenians» had nothing to do with saboteurs and should be distinguished from «Ukrainian» politicians. On the other hand, the newspaper emphasized: «This crime could not have developed, and it could not have gone beyond the detached facts of specific crimes if it had not been

\footnotetext{
${ }^{47} \mathrm{Ukr}$.: «безправних вчинків так званих пацифікаційних відділів».

${ }^{48}$ Солідарний голос політ. партій про події в краю. Діло. 1930. 1 жовтня.

${ }^{49}$ Там само.

${ }^{50}$ Інтерветція у гродського старости. Діло. 1930. 7 жовтня.

${ }^{51}$ Спростування Городського Староства. Там само. 9 жовтня.

52 Пацифікація і реванжі. Діло. 1930. 24 вересня.

${ }^{53} \mathrm{Ukr}$.: «актуалізацію протиукраїнських гасел».

54 Пацифікація і реванжі. Діло. 1930. 24 вересня.
} 
stoked by the atmosphere of hatred for the state and the government, spread among the Russian population by the Ukrainian separatist organizations and significant part of the clergy with metropolitan Sheptytskyi at the head $»^{55}$. Lack of reaction from the Ukrainians against the acts of sabotage, which had been carried out with the highest intensity since July, became the basis for such accusations. Neither the public nor the Greek Catholic Church did not openly condemn the mass demonstrations of UMO-OUN, which for Polish public opinion, could be synonymous with promoting or even participation in sabotage. The «Słowo Polskie» did not change its attitude after the «Dilo» had ostensibly admitted it was wrong about the issue and the very late publication of the pastoral letter. It was perceived as the «Dilo's» attempt to save its good image in the eyes of the League of Nations and numerous representatives of the foreign press residing in Lviv at this time ${ }^{56}$.

From the beginning of the pacification action, the newspaper was publishing information about the cooperation of the «Ruthenian» population with Polish authorities. The Polish side put forward this issue as an argument against allegations of collective responsibility of Ukrainians. Under the title: «The first results of the expedition of 1000 policemen [...] Polish people welcome them happily - Ruthenians are arming themselves with forks and axes to fight saboteurs» ${ }^{57}$, the «Słowo Polskie» described the mood prevailing among this small group of Ukrainians supporting nationalist activists, stating that «this part of the Ruthenian population which was supporting actions of the saboteurs felt depressed or even panicked $\rangle^{58}$. Ruthenians not only actively participated in protests condemning the sabotage but also called for the self-denunciation of a number of Ukrainian organizations. The «Słowo Polskie» emphasized the declarations of the part of the Ukrainian population towards the Government, as well as their willingness to help pacification divisions. In one of the articles, we read: «It is also worth mentioning that delegations of the population of several communes in Podhale region submitted today a request to the district governor asking him to refrain from reviewing these communes, and at the same time taking the obligation to maintain complete peace ${ }^{59}$.

${ }^{55} \mathrm{Pl}$.: «Zbrodnicza ta akcja nie mogłaby się rozwinąć, nie mogłaby była wyjść poza oderwane fakty konkretnych zbrodni, gdyby nie znalazła, jako pożywki, atmosfery nienawiści do państwa i do Rządu, wytwarzanej wśród ludności ruskiej bezkarnie i systematycznie przez ukraińskie organizacje separatystyczne i znaczną część kleru gr.-kat. z metropolitą Szeptyckim na czele»; Zagraniczni obserwatorzy i podżegacze a list pasterski ks. metropolity Szeptyckiego. Słowo Polskie. 1930. 25 października.

${ }^{56}$ Zagraniczni obserwatorzy i podżegacze a list pasterski ks. metropolity Szeptyckiego. Ibid. 25 października.

${ }^{57}$ Pl.: «Pierwsze wyniki ekspedycji 1000 posterunkowych [...] Ludność polska wita z radością ekspedycje - Rusini zbroją się w widły i siekiery do walki z sabotażystami».

${ }^{58} \mathrm{Pl}$.: «u tej części ludności ruskiej, która solidaryzowała się z akcją sabotażystów zauważyć się dało przygnębienie a nawet popłoch»; Pierwsze wyniki ekspedycji 1000 posterunkowych. Czytelnie «Proświty» magazynami bomb i granatów. Słowo Polskie. 1930. 24 września.

${ }^{59}$ Pl.: «Również godnym uwagi jest fakt, że delegacje ludności kilku gmin w powiecie podhajeckim złożyły dziś na ręce starosty powiatowego prośby o zaniechanie w tych gminach rewizyj, biorąc na siebie obowiązek utrzymania zupełnego spokoju»; Pacyfikacyjna ekspedycja policji sieje postrach wśród sabotażystów. Stowo Polskie. 1930. 26 września. 
However, it seems that, above all, they were led by fear of revision and possible arrests. The «Dilo» reported about villagers hiding themselves in the forests, stressing that «where troops of pacification expedition reached, there raised cry, moan and desperate scream of villagers $\rangle^{60}$. It is also known that squadrons of uhlans were sent to the towns where residents resisted the Government's orders and stayed there until the situation calmed down. Such actions must have been very tiring for the population, who, as a result, chose to remain loyal to the Polish authorities. The whole thing is, of course, a very complex problem, and it cannot be denied that some of the unaware villagers could actually protest against sabotage «spontaneously» and on their own initiative, as emphasized by the «Słowo Polskie».

Accumulation of antagonisms in Polish-Ukrainian relations since World War I has created a vicious circle between the two nations. From the beginning, UMO and later OUN led a permanent war against the Polish state. Terrorist attacks and acts of sabotage had a negative influence on the attitude of the Polish Government to the Ukrainians in Eastern Halychyna during the interwar period and contributed to more and more negative policy towards the Ukrainian minority. It only intensified anti-state activities among nationalist organizations, which allured especially young people who were often burning with desire for revenge or were driven by badly conceived patriotism. This entire «cause and effect» chain, which is highly simplified here, led to the decision to resolve the burning issue permanently. As a response to the increasing amount of acts of sabotage during the summer of 1930, the pacification campaign was conducted. In spite of all the reasons and factors that affected this decision, pacification cannot be justified, mainly because of the fact that a large part of the Ukrainians was burdened with collective responsibility for the actions taken just by some of them. It was a solution that did not comply with the legislation of that time, and from today's perspective, it should not have taken place at all. Still, the authorities considered it to be the only possible way of resolving the problem, which had the support of the greater part of Polish society. Today, it is believed that the best solution would be directing pacification actions only against saboteurs, members of the UMO-OUN, not burdening with responsibility the entire Ukrainian community. Still, it is difficult to say whether such a solution would solve the problem of a large part of Ukrainians supporting the activity of nationalists.

Taking into consideration the direct effects of pacification, it is not possible to attribute the success to any side of the conflict. Indeed, the number of acts of sabotage was reduced and, as a result of the revisions and arrests, many UMO-OUN activists were stopped. However, the «retaliatory» attacks continued, and the influence of Ukrainian nationalists among the youth still increased. The short-term truce did not guarantee the desired peace. The distance and distrust between the Poles and Ukrainians have increased. Although the Polish Government showed its strength to Ukrainians, it did not lead to the normalization of the relations; it only exacerbated them. The pacification has shown Poland in a bad light internationally as well. Ukrainians have conducted extensive propaganda in the world, as a result of which the Polish state has been deplored and

${ }^{60} \mathrm{Ukr}$.: «куди проходять відділи цієї пацифікаційної експедиції там піднімається плач, стогін та розпучливий крик сільського населення»; Українське населення криється по лісах. Діло. 1930. 27 вересня. 
gained a bad reputation in many international environments. However, the League of Nations, despite the recognition of pacification action as unjust, stated that Poland had not committed «persecution and violence on the Ukrainians $\rangle^{61}$ and was provoked by the Ukrainians who were taking revolutionary actions against the Polish state ${ }^{62}$.

\section{REFERENCES}

Akcja pacyfikacyjna ukończona. (1930, Październik 12). Stowo Polskie [in Polish]. Dokument chasu. (1930, veresnia 10). Dilo [in Ukrainian].

Echa wczorajszych aresztowań. (1930, Październik 1). Stowo Polskie [in Polish]. Głos niepokoju w prasie ruskiej. (1930, Wrzesień 22). Stowo Polskie [in Polish]. Grünberg, K., \& Sprengel, B. (2005). Trudne sąsiedztwo. Stosunki polsko-ukraińskie $w X-X X$ wieku. Warsaw; Białystok: Książka i Wiedza [in Polish].

Intervettsiia u hrodskoho starosty. (1930, Zhovten 7). Dilo [in Ukrainian].

Kwaterunek ułanów po wsiach daje dobre wyniki. (1930, Wrzesień 24). Słowo Polskie [in Polish].

Masovi revizii po selakh lvivskoho povitu. (1930, Veresen 18). Dilo [in Ukrainian].

Mazur, G. (2007). Życie polityczne polskiego Lwowa 1918-1939. Krakow: Księgarnia Akademicka [in Polish].

Mirchúk, P. (2007). Narys istorii Orhanizatsii Ukrainskykh Natsionalistiv. Kyiv: Ukrainska vydavnycha spilka [in Ukrainian].

Motyka, G. (2006). Ukraińska Partyzantka 1942-1960. Działalność Organizacji Ukraińskich Nacjonalistów i Ukraińskiej Powstańczej Armii. Warsaw: Rytm [in Polish].

Napad na pochtovyi ambulians. (1930, Serpen 1). Dilo [in Ukrainian].

Napad rabunkowy bojówki UOW na ambulans pocztowy pod Bóbrką. (1930, Sierpień 1). Stowo Polskie [in Polish].

Nici sabotaży bobreckich prowadzą do «ukraińskiego» gimn. w Rohatynie. (1930, Wrzesień 18). Stowo Polskie [in Polish].

Oczyszczenie trzech województw ze zbrodniczych elementów. (1930, Wrzesień 23). Stowo Polskie [in Polish].

Pacyfikacyjna ekspedycja policji sieje postrach wśród sabotażystów. (1930, Wrzesień 26). Stowo Polskie [in Polish].

Patsyfikatsiia i revanzhi. (1930, Veresen 24). Dilo [in Ukrainian].

Pierwsze wyniki ekspedycji 1000 posterunkowych. Czytelnie «Proświty» magazynami bomb i granatów. (1930, Wrzesien 24). Stowo Polskie [in Polish].

Prezydiia UNDO do min. Skladkovskoho. (1930, Veresen 2). Dilo [in Ukrainian].

Prywatne ukraińskie gimnazjum w Drohobyczu - zamknięte. (1930, Wrzesień 5). Stowo Polskie [in Polish].

Przeciw zakusom pruskim i bandyckim prowokacjom ukraińskim. (1930, Wrzesień 2). Stowo Polskie [in Polish].

${ }^{61} \mathrm{Pl}$.: «prześladowań oraz gwałtu na ludności ukraińskiej».

${ }^{62}$ Grünberg K., Sprengel B. Trudne sąsiedztwo. Stosunki polsko-ukraińskie w X-XX wieku. Warszawa; Białystok: Książka i Wiedza, 2005. C. 426. 
Przyczyny środowych aresztowań. (1930, Wrzesień 13). Stowo Polskie [in Polish].

Revanzhi. (1930, Zhovten 5). Dilo [in Ukrainian].

Rewizje w Żydatyczach i w okolicy. (1930, Wrzesień 7). Stowo Polskie [in Polish].

Ruskie gimnazjum arsenałem sabotażystów. Dalsze wyniki ekspedycji 1000 posterunkowych. (1930, Wrzesień 25). Stowo Polskie [in Polish].

Ruskie gimnazjum w Tarnopolu wychowuje podpalaczy. (1930, Wrzesień 22). Stowo Polskie [in Polish].

Ruskie szkoły średnie - wylęgarniami wywrotowców. (1930, Wrzesień 9). Stowo Polskie [in Polish].

Solidarnyi holos polit. partii pro podii v kraiu. (1930, Zhovten 1). Dilo [in Ukrainian].

Sprostuvannia Horodskoho Starostva. (1930, Zhovten 9). Dilo [in Ukrainian].

Szumiło, M. (2007). Ukraińska Reprezentacja Parlamentarna w Sejmie i Senacie $R P$ (1928-1939). Warsaw: Neriton [in Polish]. Polish].

Tomaszewski, J. (1985). Rzeczpospolita wielu narodów. Warsaw: Czytelnik [in

Torzecki, R. (1989). Kwestia ukraińska w Polsce w latach 1923-1929. Krakow: Wyd-wo Literackie [in Polish].

Ukrainska shkola im. kniazia Lva u Lvovi vyletila u vozdukh. (1930, Veresen 23). Dilo [in Ukrainian].

Ukrainske naselennia kryietsia po lisakh. (1930, Veresen 27). Dilo [in Ukrainian].

Wysocki, R. (2003). Organizacja Ukraińskich Nacjonalistów w Polsce w latach 1929-1939. Lublin: Wyd-wo Uniwersytetu Marii Curie-Skłodowskiej [in Polish].

Z Brześcia przewieziono do Lwowa 5 b. posłów «ukraińskich». (1930, Listopad 15). Stowo Polskie [in Polish].

Z holosiv ukrainskoi presy pro podii v kraiu. (1930, Zhovten 21). Dilo [in Ukrainian].

Za sabotowanie zarządzeń władz zakwaterowano we wsi Kurowce szwadron ułanów. (1930, Wrzesień 20). Stowo Polskie [in Polish].

Zagraniczni obserwatorzy i podżegacze a list pasterski ks. metropolity Szeptyckiego. (1930, Październik 25). Stowo Polskie [in Polish].

Zamknięcie dwóch gimnazjów ruskich. (1930, Wrzesień 29). Słowo Polskie [in Polish].

Znieważenie portretu prezydenta w lw. gimn. ruskiem. (1930, Październik 13). Stowo Polskie [in Polish].

Zniszczenie orła państwowego w gimnazjum ruskiem. (1930, Październik 27). Stowo Polskie [in Polish]. 
Магдалена ГІБЕЦЬ Докторантка (PhD) Вроилавського університету Інститут історії ORCID: 0000-0001-9217-7943 e-mail: gibiec_magda@wp.pl

\section{ОБРАЗ ПАЦИФІКАЦІЇ СХІДНОЇ ГАЛИЧИНИ 1930 РОКУ В СВІТЛІ ПОЛЬСЬКОЇ ТА УКРАЇНСЬКОЇ ПРЕСИ}

Пацифікація, проведена польською владою у Східній Галичині в 1930 р., була наслідком ескалації конфлікту та тиску з боку польської та української сторін після Першої світової війни. У результаті Ризького договору 1921 р. та згідно з ухвалами Конференції Ради послів 1923 р., значний відсоток українців опинився на польському боці кордону проти своєї волі. Спроби відновити незалежність у 1918-1919 рр. закінчилися невдачею, що лише посилило конфлікт. Крім того, неефективна національна політика Польщі, а також небажання співпрацювати з українцями унеможливлювали вирішення цього питання. Як для поляків, так і для українців Східна Галичина була державно-політичним пріоритетом. Не було такого компромісу, який міг би задовільнити очікування обох сторін. Соціальні установки серед українців сприяли радикалізації їх поглядів та призвели до активізації націоналізму. У 1920 р. була створена Українська військова організація, що поставила собі за мету продовжувати змагання за незалежність, використовуючи радикальні методи боротьби проти Польщі. Активісти УВО воювали не лише проти поляків, а й українців, готових налагодити співпрацю 3 польською владою. Наступні кілька років принесли ще більше розбіжностей, зокрема у сферах української освіти та економічних реформ, що лише поглибило конфлікт. У червні 1930 р. громадськість була проінформована про передбачувані переговори між урядом та Українським національно-демократичним об'єднанням. Це призвело до мобілізації українських націоналістів, які виступали проти будь-якої угоди. Це було пов'язано з піднесенням Організації українських націоналістів, при цьому УВО стало iї мілітарною структурою. Вживаючи кардинальних заходів, праворадикали прагнули не допустити домовленостей та актуалізувати національне питання, що призвело до так званого часткового відштовхування УВО. Спочатку саботаж, а згодом і умиротворення зачепили прямо та опосередковано величезну частину населення Східної Галичини.

В епоху, коли інших засобів масової інформації практично не було, преса стала найважливішим рупором для громадськості. Вона не лише виконувала інформативну функцію, іiї головною метою було формування думок. Преса суттєво впливала на настрої та погляди нації і навіть могла змінити спосіб дій. Маніпулюючи фактами, використовуючи правильну мову, борючись аргументами, преса змогла створити бажану картину подій. Подивившись на події крізь призму преси, можемо поглянути на них зсередини, і завдяки регулярності публікацій у пресі (у даному випадку щоденно) можемо стежити за їхнім розвитком. Метою дослідження $\epsilon$ представлення вибраних питань, пов'язаних із подіями, які історіографія називає «умиротворенням Східної Галичини», з урахуванням архівних матеріалів, а також польської та української громадської думки, висловленої в пресі: «Słowo Polskie» та «Діло».

Ключові слова: пацифікація, польська та українська громадськість, Східна Галичина, Український національно-демократичне об'єднання, Українська військова організація, Організація українських націоналістів, польський уряд. 